\title{
Evaluating grazing strategies for cattle: Deer and cattle food partitioning
}

\author{
ISAAC M. ORTEGA, SERGIO SOLTERO-GARDEA, FRED C. BRYANT, AND D. LYNN DRAWE
}

Authors are research associate, former graduate student, former professor, and assistant director, Department of Range, Wildlife, and Flsheries Management, Texas Tech University, Lubbock, Tex. 79409-2125 (IMO); Instituto Nacional de Investigaciones Forestales y Agropecuarias, Jalisco, Mexico (SSG), Welder Wildlife Foundation, P.O. Box 1400, Sinton, Tex. 78387 (DLD), and Caesar Kleberg Wildlife Research Institute, TAMU-Kingsville, Kingsville, Tex. 78363 (FCB).

Abstract

We studied resource partitioning between cattle and deer (Odocoileus virginianus Boddaert) within replicated treatments of continuous and short-duration grazing at heavy and moderate stocking rates. We recorded food habits using the bite-count technique with tame white-tailed deer, and the esophageal fistula technique with steers. Through use of canonical discriminant analysis, we found diets of cattle and deer to be distinct $(P<0.05)$ from each other in every treatment throughout the sampling period. Overall, deer used mostly forbs (72\%) whereas cattle primarily used grasses $(60 \%)$ and forbs $(39 \%)$. We also evaluated sensitivity to pasture conditions created by cattle grazing by comparing diets across treatments, especially during the summer months (May through September) and the second winter, which was affected by drought. Out of a possible 48 treatment combinations compared, deer selected different diets 21 times whereas cattle selected different diets 16 times. Deer were more sensitive than cattle to grazing treatments. Cattle were most sensitive to treatments during the first summer and second winter. Deer were the least sensitive to the grazing treatments during spring, when their diets were similar across all treatments. We recommend moderate stocking rates to reduce dietary overlap between cattle and deer and continuous grazing or less intensive grazing systems to create an environment where deer can select greater amounts of forbs.

Key Words: white-tailed deer, Odocoileus virginianus, cattle, food habits, Coastal Bend of Texas, short-duration grazing, continuous grazing

Animal species that share a common resource may use different strategies to exploit it. Environmental factors such as drought or wet periods, and animal characteristics such as mouth morpholo-

Research was funded by the Welder Wildlife Foundation and in part by the Office of Agriculture, Bureau of Research and Development, U.S. Agency for International Development under Grant No. DAN-1328-G-00-0046-00.

Authors thank J. Teer, J. Cox, B. Martinez, I. Berger, L. Perry, and many others for their contribution in the field and lab work. We would also like to thank $D$. Haukos for assistance in statistical analyses and C. Britton, E. Laca, and R. Mitchell for their critical reviews and suggestions on early drafts of this manuscript. Welder Wildlife Foundation contribution No. 476. This is a College of Agriculture and Natural Resources TTU publication T-9-744.

Manuscript accepted 22 Dec. 1996
Resúmen

Estudiamos las partición de recursos entre el vacuno y el ciervo de cola blanca (Odocoileus virginianus Boddaert) usando tratamientos replicados de pastoreo continuo y corta duración bajo carga animal alta y moderada. Para el registro de los hábitos alimenticios se uso la técnica de conteo de mordiscos con los ciervos, y con el vacuno se utilizaron novillos fistulados. A través del análisis canónico discriminatorio, encontramos que las dietas del vacuno y ciervos son distintas $(P<0.05)$ entre si en cada tratamiento a través del periodo de muestreo. En general, los ciervos usaron mas hierbas $(72 \%)$ en tanto que los vacunos usaron principalmente pastos $(60 \%)$ y hierbas $(39 \%)$. Evaluamos además, la sensibilidad de las condiciones del pastizal, creadas por el pastoreo de los vacunos, basándonos en una comparación de las dietas a través de los tratamientos, especialmente durante los meses de verano (mayo a septiembre) y durante el segundo invierno, el cual fue afectado por la sequía. De las posibles 48 combinaciones de la comparación de tratamientos, los ciervos seleccionaron 21 veces dietas diferentes, en tanto que los vacunos seleccionaron un total de 16 veces dietas diferentes. Los ciervos fueron mas sensibles que los vacunos al pastoreo. Los vacunos fueron mas sensibles a los tratamientos durante el primer verano y el segundo invierno. Los ciervos fueron menos sensibles a los tratamientos de pastoreo durante la primavera, cuando sus dietas fueron similares a través de todos los tratamientos. A modo de reducir la sobreposición alimenticia entre el vacuno y los ciervos, recomendamos usar una carga animal moderada y un pastoreo continuó sistemas de pastoreo menos intensivo para crear un medio donde el ciervo pueda seleccionar mayores cantidades de hierbas.

gy, gut morphology, and physiology, body size, and behavior are proximate factors that shape such strategies (Bryant 1981).

Livestock management can affect the strategy used by wild ungulates to exploit resources. Factors such as grazing systems and stocking rates could increase the pressure on wild species for a rapid adaptation to the newly created environment. This may be the case when white-tailed deer (Odocoileus virginianus Boddaert) interact with cattle under grazing systems imposed by man.

Continuous grazing has been the traditional practice for many years, until short-duration grazing was introduced in the U.S.A. (Savory and Parson 1980, Heitschmidt et al. 1982). The conflict between grazing methods arises when a rancher desires profits 
from both wildlife and livestock without negatively affecting the wild species or rangeland health.

Studies have been conducted in many regions to evaluate different grazing systems and stocking rates, but little is known about how short-duration and continuous grazing under different stocking rates affect cattle or deer in the Texas Coastal Bend. The objectives of this study were to determine the botanical composition of diets for cattle and deer under short-duration and continuous grazing, each under heavy and moderate stocking rates, and to compare the dietary resource partitioning between cattle and deer under these conditions.

\section{Materials And Methods}

The study was conducted at the Rob and Bessie Welder Wildlife Refuge, San Patricio County, Tex. Further discussion of the study site is found in Ortega et al. (1997a).

Diet sampling was conducted with cattle and deer on 2 grazing systems (short-duration and continuous grazing) and 2 stocking rates (heavy and moderate) from October 1987 to July 1989. Treatments were replicated. Moderate stocking rates were set at 1 AU/4.9 ha/yr, a stocking rate commonly used in the Coastal Bend. Pastures receiving heavy stocking rates were stocked at twice the moderate rates, $1 \mathrm{AU} / 2.4 \mathrm{ha} / \mathrm{yr}$.

Treatments and replications were located in areas with similar grazing histories since 1974 . The short-duration grazing treatments were part of a pasture historically grazed under a 1-herd, multi-pasture system similar to short-duration grazing (Drawe and Cox 1979), whereas the continuous treatment was located on an area historically grazed continuously. Short-duration and continuous grazing pastures were stocked with cattle in March 1987. Replications of short-duration grazing treatment were subjected to a rigid rotation of $\mathbf{2 8}$ days of rest (no cattle grazing) and 4 days of grazing. Cattle that grazed the short-duration grazing treatments were rotated to a nearby pasture when the short-duration grazing pastures were being rested. Deer were held in an adjacent pasture until each foraging trial. The close proximity of the treatment to the holding pastures allowed the experimental animals (deer and cattle) to remain in the vicinity for access as well as for conditioning to seasonal changes of the flora.

\section{Cattle and Deer Diets}

We obtained cattle diet samples in each replication 2-days per month from 5 randomly selected, esophageally fistulated steers from a group of 12 animals. Fistulated steers were kept in the vicinity of the treatment pastures year-round. To increase appetite, steers were penned the night before sampling without food or water for at least 12 hours. Diet samples were collected in the early morning. Extrusa was collected in screen-bottom canvas bags. Steers were kept in the pasture treatments for at least 1 hour. After sampling, the canvas bag was removed and the animals were free to graze in a 1.7-ha adjacent pasture. Extrusa samples were allowed to drain in the collection bag for at least 2 hours. A subsample of the diet was preserved in ethyl alcohol and prepared for microhistological analysis according to Scott and Dahl (1980). A total of 708 samples was collected. An aliquot of each sample was mounted on 5 microscope slides (see Ortega et al. 1995). From each slide, 20 fields were read to identify plant species based on a reference collection of the plant specimens previously collected in the field. Botanical composition was determined at the Department of Range, Wildlife, and Fisheries Management, Texas Tech University. According to previous studies (Kie et al. 1980, Sanders et al. 1980) there was no need to correct for over- or under-estimation of the microhistological readings unless plants occurring in trace amounts occur disproportionately high in the diet. The few species that could have been over- or under-estimated, such as sida (Sida filicaulis Torr. and Gray), had a very low availability ( $<2.0 \%$ frequency) and never comprised more than $2.0 \%$ of the diet of either ungulate.

Tame deer were used to obtain information on deer diets. Only does were used in this experiment, which should provide sexunbiased deer diet information (La Gory et al. 1991). Five does were born in 1986 and 5 in 1987, and all of them were under similar physiological status. Detailed explanation on raising and care of deer used in this study are found in Ortega et al. (1990) and Ortega (1991). During non-sampling periods, the routine was for deer to be kept inside of a pen $\left(784 \mathrm{~m}^{2}\right)$ at night, whereas during the day for about 10 hours, they were allowed to roam and feed in a holding pasture $(0.5 \mathrm{ha})$ of vegetation similar to the treatment pastures. Deer were supplemented with $750 \mathrm{~g} /$ deer/day of $16 \%$ protein pellets and $750 \mathrm{~g} /$ deer of alfalfa hay every other day. To increase the appetite of deer during morning foraging trials, alfalfa hay was not provided and the animals were allowed to stay in the holding pasture for only 4-5 hours the day before the sampling.

Foraging trials were conducted in early morning from 0630 to 0830 hours, lasting an average of $38 \mathrm{~min}$. (range $=25-85 \mathrm{~min}$.). Observations were conducted by the same observer of 4 randomly selected deer (from a total of 9 deer available for sampling) in each replication 1-day per month for 22 months. On the day of each trial, 4 deer were taken to a pre-determined treatment pasture (replication) by having the deer follow the observer. An assistant herded the deer toward the pastures to prevent feeding in transit. When in the pasture, deer were allowed to roam freely. The observer did not influence the direction deer traveled, except when a deer tried to move to another replication pasture. Deer were sequentially observed feeding for 25 bites to complete a minimum of 100 bites per deer. Bite-count data consisted of recording only plant species that the deer consumed; no data were recorded on plant parts consumed. Data were recorded on tape and transcribed to a computer the same day. A total of 68,239 bites was recorded over the study period. Botanical names and plant identification follow taxonomy by Gould and Box (1965) and Jones (1982).

\section{Data Analysis}

Data were analyzed seasonally in order to interpret effect of treatment on ungulate diets. Seasons were established according to growing season of the vegetation and climatic patterns. They are as follows: for Year 1, fall: October and November 1987; winter: December 1987, January and February 1988; spring: March and April 1988; summer: May, June, July, August, and September 1988; and for Year 2, fall: October and November 1988; winter: December 1988, January and February 1989; spring: April and May 1989; and summer: June and July 1989.

Cattle and deer diets were analyzed using canonical discriminant analysis, a multivariate statistical technique that allows study of differences between 2 or more groups simultaneously (Klecka 1980, Lindeman et al. 1980). This technique also has been used by Hanley and Hanley (1982) to study resource partitioning 
among ungulates. Discriminant analysis permits the separation of deer and cattle diets under any of the treatments if they were eating different plant species. In contrast, if deer or cattle diets under any of the treatments were eating similar forages, they would not be separated (Green 1971).

Discriminant analysis was applied to the diet data pooled across all seasons, as well as within seasons. In both instances, plant species comprising less than $5 \%$ of the diet in any one of the 8 groups (4 treatments $\times 2$ ungulates) were not included. The most valuable plant species to discriminate between the diets of ungulates or the diets as affected by the treatments, were revealed by the discriminant function coefficients (Hanley and Hanley 1982). To test for statistical significance among groups, the $\mathrm{F}$ ratio for the Mahalanobis distance between each pair of groups was calculated (Hanley and Hanley 1982, Lindeman et al. 1980). Separate analysis for deer and cattle diets using forage classes were analyzed using the General Linear Model of Statistical Analysis System (SAS 1985) through a completely randomized design with a split-plot in time arrangement (Steel and Torrie 1980). Pastures within grazing systems (GS) and stocking rate (SR) were considered replications (Rep). Grazing systems and stocking rates were whole plots with seasons as the split-plot. The error term for testing significant effects of grazing systems and stocking rate was Rep $\times$ SR (GS). Error term used for testing season was Rep $X$ GS X SR $\times$ Seasons. Differences between means were determined using Fisher's protected least significant difference (LSD) procedure $(\alpha=0.05)$ (Ott 1988).

The Morisita-Horn index (Magurran 1988) was used to determine diet overlap between cattle and deer (Schwartz and Ellis 1981). This index is recommended by Wolda (1981) to avoid the complex dealings with effects of sample size and diversity.

\section{Results}

\section{Grazing Treatment Effects on Diets}

Through canonical discriminant analysis, we found cattle and deer diets to be distinct $(P<0.001)$ from each other in every treatment across the entire sampling period (Fig. 1). As indicated by the distances between the centroids, in most of the seasons, diets were similar in composition 32 out of 48 tests (67\%), and comparing cattle versus cattle, 27 of 48 tests $(56 \%)$ comparing deer versus deer under the numerous treatments (Table 1).

Overall, disregarding treatments, cattle ate mostly grasses and forbs, whereas deer ate forbs (Table 2). Deer mostly consumed wood-sorrel (Oxalis dillenii Jacq.), clay violet (Ruellia nodiflora (Gray) Urban), and bundle flower (Desmanthus virgatus (L.) Wild.), whereas cattle primarily ate grasses: pink tridens (Tridens congestus (L.H. Dew.) Nash.), buffalograss (Buchloe dactyloides (Nutt.) Engelm.), and Texas wintergrass (Stipa leucotricha Trin. and Rupr.). These were the primary plant species separating deer diets from cattle diets. The second discriminant function explains the effects of grazing systems on diets. Consumption by deer of tropical dayflower (Commelina elegans H.B.K.), widow's tear (C. erecta L.), prairie coneflower (Ratibida columnaris (Sims) D. Don), and western ragweed (A. psilostachya DC.), and consumption by cattle of little bluestem (Schizachyrium scoparium (Michx.) Nash.), and longtom (Paspalum lividum Trin.) were the key plants that separated cattle and deer diets when foraging in the continuous compared with short-duration grazing pastures.

According to univariate analysis, neither the grazing system nor

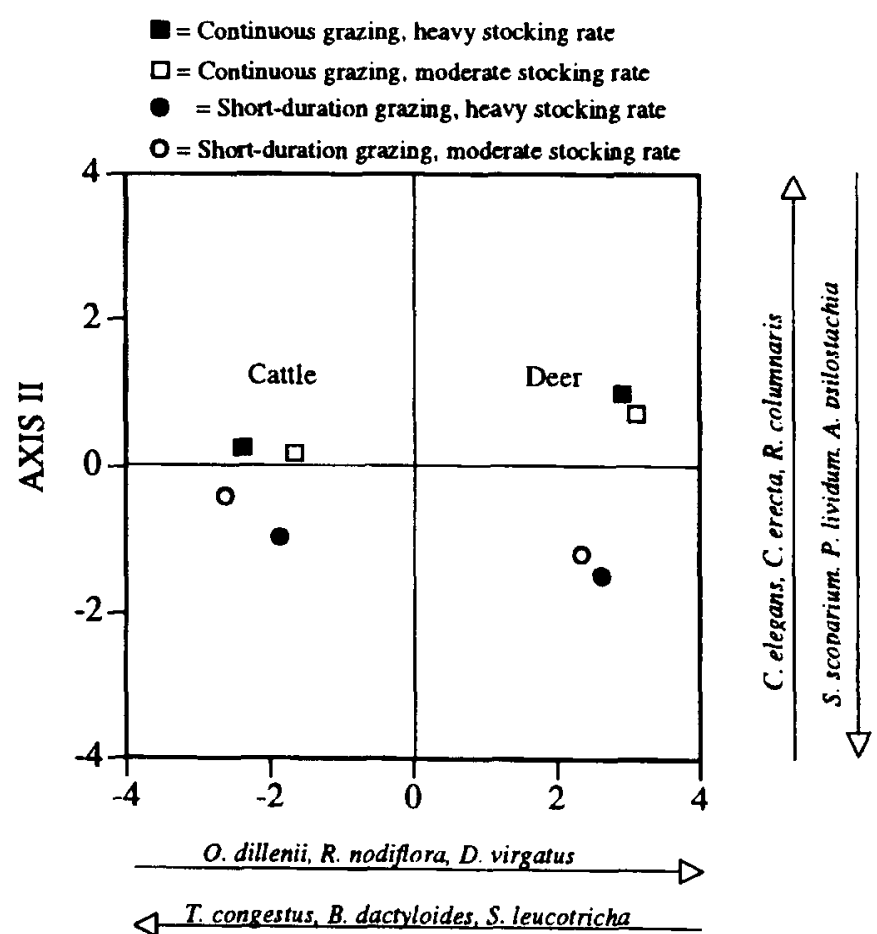

AXIS I

Fig. 1. Plot of canonical discriminant centroids of cattle and deer diets for each grazing treatment pooled across seasons. Direction of arrows bordering the axis indicates most valuable plant species for discriminating between the diet composition of the various groups.

stocking rate affected $(\mathrm{P}>0.05)$ the use of forbs, grasses, or browse (Table 3 ) by cattle and deer. However, data indicated that cattle and deer consumed more forbs and less grasses under continuous than short-duration grazing, and cattle tended to consume greater amounts of forbs and less grasses under heavy than moderate stocking rates. We observed no trends for white-tailed deer in their response to stocking rates (Table 3).

Multivariate statistics (Table 1), revealed a more comprehensive index of deer sensitivity to grazing treatments. Cattle were highly sensitive to the vegetation conditions during the first summer of the study, in which they selected different diets $(P<0.005)$ for each treatment (Table 1). Deer were most sensitive to summer conditions during both years, because diets were generally different $(P<0.01)$ when deer grazed in the various treatment pastures. After the summer period, deer were most sensitive to grazing treatments in winter during the drought, followed by fall of the second year. Deer were least sensitive to treatment pastures during the spring both years (Table 1).

Across seasons, cattle were less sensitive to the conditions created by continuous than short-duration grazing. Cattle foraging in continuously grazed pastures only had different diets in 2 out of 8 seasons, whereas under short-duration grazing, cattle diets were different in 4 out of 8 seasons (Table 1). Deer were least sensitive to conditions created by stocking rates within grazing systems. For example, within continuous grazing deer were sensitive to stocking rate (diets were different between continuous heavy and moderate) in only 2 of 8 seasons (Table 1). Similarly, within short-duration grazing, deer were sensitive to stocking rate only 
Table 1. Levels of significance for interactions using discriminant analysis to contrast cattle-cattle and deer-deer diets under different treatments throughout the study period at the Welder Wildife Refuge.

\begin{tabular}{|c|c|c|c|c|c|c|c|c|}
\hline \multirow[b]{2}{*}{ Contrasts } & \multicolumn{4}{|c|}{ Year 1} & \multicolumn{4}{|c|}{ Year 2} \\
\hline & Fall & Winter & Spring & Summer & Fall & Winter & Spring & Summer \\
\hline \multicolumn{9}{|c|}{ Cattle-Cattle } \\
\hline $\mathrm{CM}^{*} \mathrm{CH}^{1}$ & $\mathrm{~ns}^{2}$ & ns & ns & $* *$ & ns & $* * *$ & ns & ns \\
\hline $\mathrm{SH}^{*} \mathrm{CH}$ & ns & ns & ns & $*$ ** & ns & ns & ns & ns \\
\hline $\mathrm{SH}^{*} \mathrm{CM}$ & ns & ns & ns & $* * *$ & ns & $* *$ & $* *$ & ns \\
\hline $\mathrm{SM}^{*} \mathrm{CH}$ & ns & $\mathrm{ns}$ & ns & $* * *$ & ns & $* *$ & $*$ & $* *$ \\
\hline $\mathrm{SM}^{*} \mathrm{CM}$ & ns & ns & ns & $* * *$ & $* *$ & ns & ns & ns \\
\hline SM*SH & ns & ns & ns & $* * *$ & ns & $* *$ & $* *$ & $*$ \\
\hline \multicolumn{9}{|l|}{ Deer-Deer } \\
\hline $\mathrm{CM}^{*} \mathrm{CH}$ & ns & ns & ns & ns & ns & $* *$ & ns & * \\
\hline SH*CH & ns & $* *$ & ns & $* * *$ & ns & $* * *$ & ns & $* * *$ \\
\hline $\mathrm{SM}^{*} \mathrm{CH}$ & ns & $* *$ & ns & $* * *$ & ns & $* * *$ & ns & $* * *$ \\
\hline $\mathrm{SH} * \mathrm{CM}$ & ns & $* *$ & ns & $* * *$ & $* *$ & $* * *$ & ns & $* *$ \\
\hline$S M * C M$ & ** & ns & ns & $* * *$ & $* *$ & $* * *$ & ns & $* *$ \\
\hline SM*SH & ns & ns & ns & ns & ns & $* *$ & ns & ns \\
\hline
\end{tabular}

${ }_{2} \mathrm{C}=$ continuous grazing, $\mathrm{S}=$ short-duration grazing, $\mathrm{H}=$ heavy stocking rate. $\mathrm{M}=$ moderate stocking rate.

2 Asterisks indicate significant difference between the groups when compared between 2 treatments within seasons: ${ }^{*}=\mathrm{P}<0.01 ; * *=\mathrm{P}<0.005 ; * * *=\mathrm{P}<0.001$, ns $=$ not significant $(\mathrm{P}>\mathbf{0 . 0 1})$.

in winter of the second year. Deer were most sensitive to vegetation conditions between grazing systems such as continuous moderate vs. short-duration moderate and continuous moderate vs. short-duration heavy. Diets were different in 10 of 16 comparisons. In general, summer periods and winter drought intensified selectivity by both ungulates (Table 1 ).

Diet composition by season varied between cattle and deer under the different treatments. However, diets of cattle and deer were different throughout the 22-month sampling period as indicated by the first discriminant function (Table 4).

\section{Year 1}

During fall, cattle diets were similar across all treatments (Table 1 and 4; Fig. 2). Deer diets were similar in all treatments except between grazing systems at moderate stocking (Table 1 and 4; Fig. 2). This dietary difference between grazing systems affected nutrient levels. Dietary crude protein for deer under short-duration was at the maintenance level $(9.9 \%)$, whereas in the continuous grazing it was greater than maintenance $(11.4 \%)$ (Soltero-Gardea 1991; Ortega et al. 1997b). During fall deer in the short-duration grazing used more grasses $(40 \%)$ such as longtom and only $30 \%$ forbs, whereas under continuous grazing deer used mainly forbs (50\%), browse (mesquite beans [Prosopis gladulosa Torr.] ), and very little grass (Fig. 2).

In winter, cattle diet composition under the different treatments was still similar, whereas deer diets were affected by grazing systems, but not stocking rate (Table 1 and 4; Fig. 2). Deer used more forbs under continuous than short-duration grazing, which

Table 2. Forage classes (dietury percent) used by deer and cattle throughout the study, 1987-1989 at the Welder Wildlife Refuge.

\begin{tabular}{lccc}
\hline \hline Species & Forbs & Grasses & Browse \\
\hline & $\ldots$ & 59.9 & 1.0 \\
Cartle & 39.1 & 0.6 & 0.1 \\
SE $^{1}$ & 0.6 & 14.2 & 13.6 \\
Deer & 72.2 & 0.6 & 0.8 \\
SE & 1.0 & &
\end{tabular}

resulted in high dietary crude protein (Range: 13.7 to $15.3 \% \mathrm{CP}$ ) (Soltero-Gardea 1991; Ortega et al. 1997b). Species such as prairie coneflower and false dandelion (Pyrrhopappus multicaulis D.C.) were important to deer diets at this time.

During spring, cattle diets were similar across all trealments, as were deer diets (Table 1; Fig. 2). Deer and cattle increased use of forbs from winter to spring (Fig. 2), but the dietary crude protein level dropped for deer (from 14.5 to 12.6\%) but increased for cattle(from 8.0 to $9.2 \%$ ) (Soltero-Gardea 1991; Ortega et al. 1997b). Diets differed so in botanical composition that we were unable to explain this phenomenon.

In summer, both cattle and deer diets were sensitive to grazing systems, whereas cattle diets also were affected by the stocking

Table 3. Forage classes (dietary percent) used by cattle and deer as influenced by grazing systems and stocking rates at the Welder Wildlife Refuge.

\begin{tabular}{|c|c|c|c|}
\hline Cattle & Forbs $^{1}$ & Grasses & Browse \\
\hline Grazing System & \multicolumn{3}{|c|}{$\ldots \ldots(\%) \ldots \ldots$} \\
\hline Short-duration & 36.2 & 63.2 & 0.6 \\
\hline$S E^{2}$ & 0.8 & 0.8 & 0.2 \\
\hline Continuous & 41.8 & 56.7 & 1.5 \\
\hline SE & 0.8 & 0.8 & 0.06 \\
\hline \multicolumn{4}{|l|}{ Stocking Rate } \\
\hline Heavy & 42.9 & 55.8 & 1.3 \\
\hline $\mathrm{SE}$ & 0.8 & 0.8 & 0.2 \\
\hline Moderate & 35.2 & 64.1 & 0.7 \\
\hline SE & 0.8 & 0.8 & 0.09 \\
\hline \multicolumn{4}{|l|}{ Deer } \\
\hline \multicolumn{4}{|l|}{ Grazing System } \\
\hline Short-duration & 68.7 & 18.7 & 12.6 \\
\hline $\mathrm{SE}$ & 1.3 & 1.0 & 0.9 \\
\hline Continuous & 76.0 & 9.4 & 14.6 \\
\hline SE & 1.3 & 0.6 & 1.2 \\
\hline \multicolumn{4}{|l|}{ Stocking Rate } \\
\hline Heavy & 71.8 & 14.4 & 13.8 \\
\hline SE & 1.3 & 0.8 & 1.1 \\
\hline Moderate & 72.7 & 14.0 & 13.3 \\
\hline SE & 1.3 & 0.9 & 1.1 \\
\hline
\end{tabular}

No difference $(P>0.05)$ were observed within animal species means for forage classes when comparisons between grazing systems or stocking rates were made.
${ }^{2}$ Standard error. 

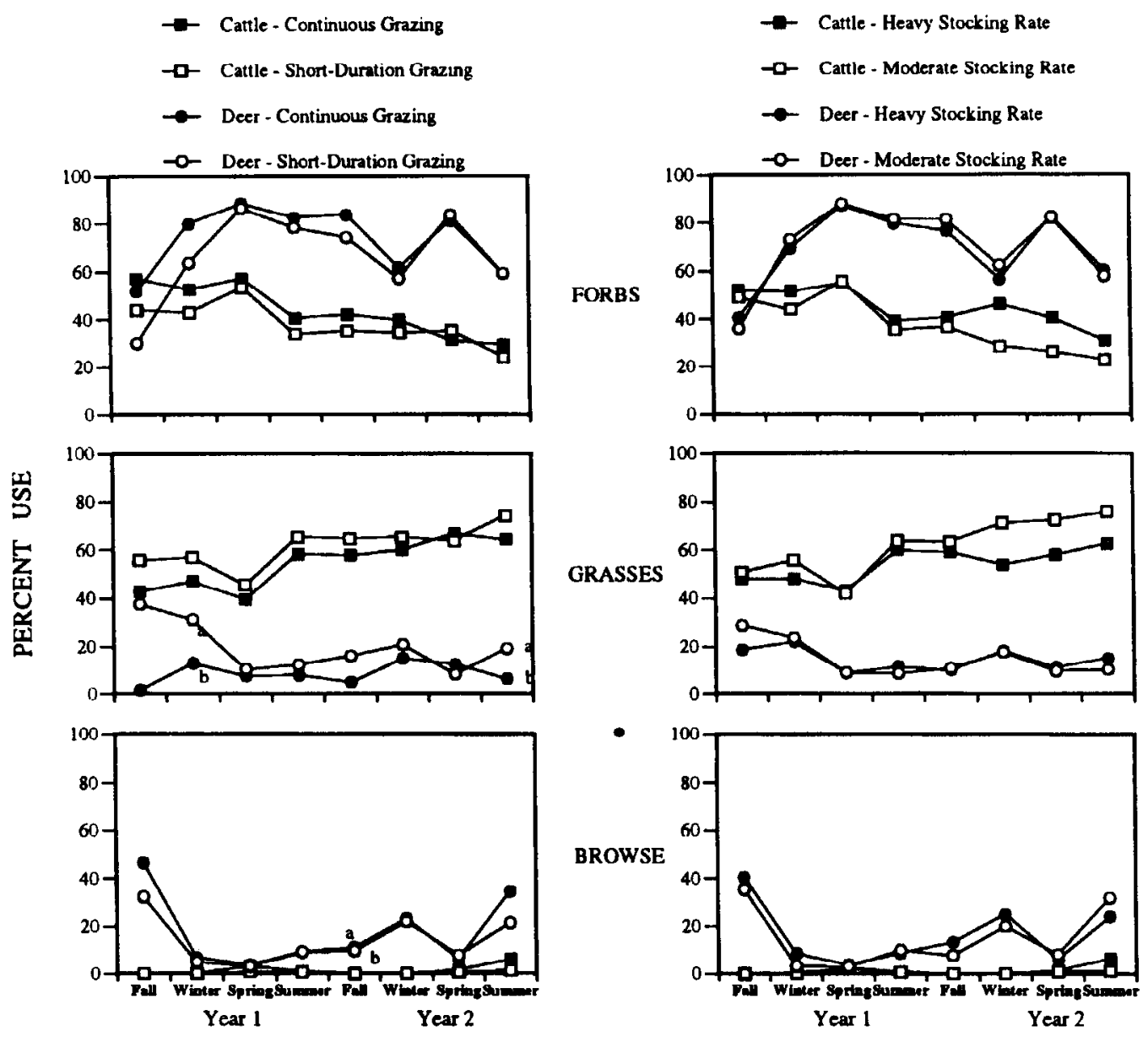

Fig. 2. Use of forbs, grasses, and browse by deer and cattle under continuous and short-duration grazing systems, and heavy and moderate stocking rates. Different letters indicate difference within season $(P<0.05$ ). No letters indicate no difference within season.

rates (Table 1 and 4; Fig. 2). By this time of the year, deer were concentrating heavily on patches of wood-sorrel, especially under moderate stocking rates. Deer diets under continuous grazing contained more tropical dayflower and widow's tear than in the short-duration grazing treatments, whereas western ragweed, loosestrife (Lythrum californicum Torr. \& Gray) and longtom were used more by deer in the short-duration than in the continuous grazing treatments. False garlic (Nothoscordum bivalve (L.) Butt.), prairie coneflower, and clay violet were used by deer in greater proportion under heavy than in the moderate stocking rates. Buffalograss was used by deer more in the continuous than in the short-duration grazing, whereas the opposite was true for longtom. Cattle used wood-sorrel and sawtooth frogfruit (Phyla incisa Small) in greater proportions under continuous than in the short-duration grazing. Hall's panicum (Panicum hallii Vasey), longtom and little bluestem were used by cattle mostly in the short-duration compared to continuous grazing treatments. Buffalograss and pink tridens were used by cattle in any of the treatments in higher proportion than any other grass species.

\section{Year 2}

During fall, cattle diets were different only between short-duration and continuous grazing under moderate stocking (Table 1 and 4; Fig. 2). Cattle used western ragweed in greater proportion in the short-duration treatments than in the continuous grazing, whereas the opposite was true for sawtooth frogfruit. Some of the grasses used by cattle were buffalograss, little bluestem (especially in the short-duration grazing treatments), Texas wintergrass (greater use in the continuous grazing treatments), and pink tridens. Deer diets were affected by short-duration grazing under both stocking rates compared with the continuous grazing moderate treatment (Table 1 and 4; Fig. 2). Forbs consumed by deer during this season were tropical dayflower, widow's tear (mostly under continuous grazing), loosestrife (mostly in the short-duration grazing moderate), and wood-sorrel (in every treatment, but lower in the continuous grazing moderate).

In winter, both grazing systems and stocking rates affected deer, whereas stocking rates affected cattle (Table 1 and 4; Fig. 2), making their diet composition different. Once again deer fed heavily on the patches of wood-sorrel except in the short-duration grazing heavy treatment. Little bluestem was used by deer more in the short-duration than in the continuous grazing treatments, whereas the sedge tapeleaf flatsedge (Cyperus acuminatus Torr. and Hook.) was used more in the moderate than in the heavy treatments. In this season deer used less forbs and more browse than normal. From winter to the end of the study period, cattle used more grasses and less forbs under moderate compared to heavy stocking (Fig. 2). Cattle under the moderate stocking rate had a level of dietary crude protein below their maintenance level and $2 \%$ below crude protein values for cattle under heavy stock- 
Table 4. Centroid location of the different groups along the first canonical axis 1 .

\begin{tabular}{|c|c|c|c|c|c|c|c|c|}
\hline \multirow[b]{2}{*}{ Groups } & \multicolumn{4}{|c|}{ Year l } & \multicolumn{4}{|c|}{ Year 2} \\
\hline & Fall & Winter & Spring & Summer & Fall & Winter & Spring & Summer \\
\hline \multicolumn{9}{|l|}{ Cattle under: } \\
\hline \multicolumn{9}{|l|}{ Continuous } \\
\hline Heavy & 6.57 & 5.10 & -4.09 & -2.98 & -3.95 & 2.76 & -2.67 & 4.28 \\
\hline Moderate & 8.09 & 5.17 & -5.12 & -3.83 & -3.38 & 3.91 & -4.18 & 4.27 \\
\hline \multicolumn{9}{|l|}{ Short-duration } \\
\hline Heavy & 7.81 & 4.53 & -4.15 & -3.93 & -3.07 & 2.91 & -2.76 & 4.27 \\
\hline Moderate & 7.97 & 4.76 & -3.39 & -4.38 & -3.21 & 3.54 & -3.97 & 5.14 \\
\hline \multicolumn{9}{|l|}{$\begin{array}{l}\text { Deer under: } \\
\text { Continuous }\end{array}$} \\
\hline Heavy & -10.56 & -4.50 & 3.31 & 4.34 & 5.69 & -3.88 & 4.21 & -6.51 \\
\hline Moderate & -8.96 & -4.02 & 2.41 & 4.34 & 4.45 & -4.36 & 4.25 & -6.07 \\
\hline \multicolumn{9}{|l|}{ Short-duration } \\
\hline Heavy & -11.22 & -3.85 & 3.37 & 4.08 & 3.60 & -3.58 & 3.95 & -5.44 \\
\hline Moderate & -9.35 & -3.67 & 3.47 & 4.62 & 3.29 & -4.03 & 4.56 & -5.15 \\
\hline Canonical Correlation & 0.99 & 0.91 & 0.95 & 0.96 & 0.94 & 0.96 & 0.96 & 0.97 \\
\hline \multicolumn{9}{|l|}{$\begin{array}{l}\text { Relative percentage of } \\
\text { eigenvalue associated } \\
\text { with the first }\end{array}$} \\
\hline discriminant function & 79.3 & 78.0 & 86.1 & 91.9 & 73.8 & 83.6 & 83.3 & 77.3 \\
\hline
\end{tabular}

ing. This was attributed to greater consumption of buffalograss under moderate than heavy stocking, which was lower in crude protein than at any other time during the study (Soltero-Gardea 1991; Ortega et al. 1997b).

Crude protein in cattle diets increased during spring, but levels were still well under the maintenance level under moderate compared to heavy stocking (Soltero-Gardea 1991; Ortega et al. 1997b). Cattle diets also were affected by grazing systems (Table 1 and 4). Cattle consumed lower amounts of forbs, in all of the treatments, than the previous season (Fig. 2). By this time of the year the phytomass in general was very low in all treatments (SolteroGardea 1991; Ortega et al. 1997b). Deer diets were not affected by any treatment during the spring (Table 1 and 4; Fig. 2). However, deer increased their consumption of forbs from winter to spring.

In summer, during the peak of the drought, phytomass was at the lowest level recorded during the study, but both deer and cattle had dietary crude protein above maintenance (Soltero-Gardea 1991; Ortega et al. 1997b). Composition of deer diets was strongly affected by grazing systems and stocking rates (Table 1 and 4, Fig. 2). Deer decreased their use of forbs switching primarily to brasil (Condalia hookeri M.C. Johnst.) especially under continuous grazing compared to short-duration grazing. Wood-sorrel was practically gone by this season (Ortega et al. 1997a). The only readily available forb was bundleflower, which was eaten by deer. Buffalograss was an important item in cattle diets.

\section{Dietary Overlap}

Dietary overlap between cattle and deer was lowest in fall and summer regardless of treatment because deer used forbs and browse and cattle used grasses and forbs (Fig. 3). Greatest overlap the first year between the diets of cattle and deer (approximately 50\%) occurred in winter and spring in all treatments, a time when both species were consuming similar plant species (forbs such as western ragweed, carolina geranium (Geranium carolinianum L.), evening primrose (Oenothera speciosa Nutt.), and wood-sorrel. The high degree of overlap (>20\%) occurred during winter and spring the second year in the heavy stocking rates compared to moderate stocking (Fig. 3). Bladderpod (Lesquerella lindheimeri (Gray) Wats.), a forb highly used by both deer and cattle, probably accounted for this overlap. Each winter the greatest dietary overlap between cattle and deer was in the short-duration, heavy stocking treatments (Fig. 3).

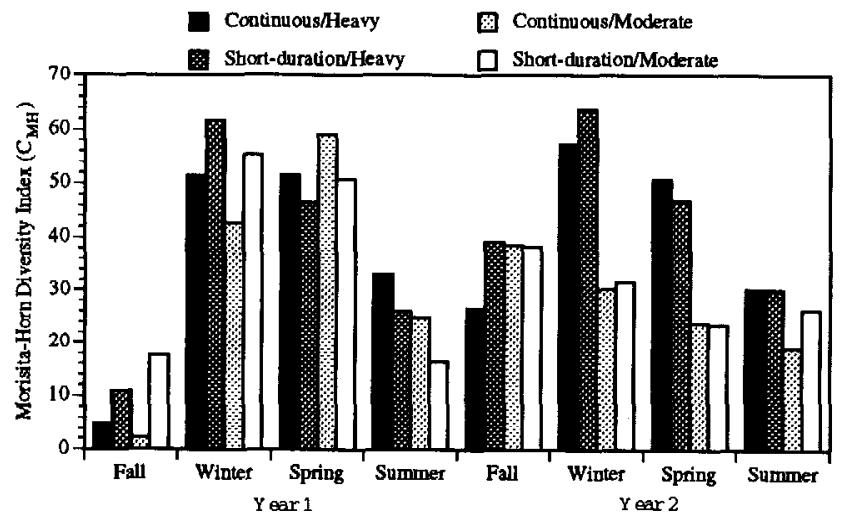

Fig. 3. Dietary overlap between cattle and deer under continuous and short-duration grazing systems and heavy and moderate stocking rates.

\section{Discussion}

\section{Resource Partitioning}

The belief that deer and cattle compete for food resources in the Texas Coastal Bend under different grazing practices is a constant concern for ranchers and biologists. If cattle and deer were both at high densities so as to create exploitative competition, in which inhibitory effects occur from reduced availability of a common resource (Pianka 1983, Keddy 1989), deer would likely be the species to suffer the most. Most sympatric species partition their environmental resources (Franklin 1982, San Martin and Bryant 1987). This partitioning can be achieved in 3 basic ways: temporally, spatially, and trophically, which will reduce competition allowing the coexistence of both species (Pianka 1973). In 
the case of cattle and deer interactions in the Texas Coastal Bend, these 2 species partition the resource temporally by feeding at different times of the day. Cattle usually feed regularly throughout the day, whereas deer do most feeding in the early morning or evening. They also partition the resources spatially. It has been demonstrated that deer will move out when cattle are concentrated into a short-duration grazing (Hyde 1987, Cohen et al. 1989a; 1989b) or high-intensity low-frequency (HILF) paddock (Adams 1978).

The question we addressed in this study focused on trophic partitioning. In short, are these 2 animal species able to partition food resources? According to discriminant analyses, the answer is a qualified yes. Drought and greater stocking rates impact deer by forcing greater dietary overlap for forbs between these ungulates. Cattle and deer have different adaptations to herbivory. Most large herbivores, such as cattle, are adapted to eat a variety of plants low in digestibility and crude protein. Their rumen morphology, relative to small herbivores, is better adapted to digest diets containing large amounts of fiber (i.e., grasses) (Bryant 1981). Small-bodied ungulates, such as deer, require a greater concentration of digestible energy. They will select more nutritious and digestible diets than large ungulates (Nagy et al. 1969, Schwartz and Ellis 1981, Demmet and Van Soest 1983). Whitetailed deer have been thus classified as a "concentrate selector" able to use plants with a greater content of crude protein (i.e., forbs, browse); whereas, cattle have been classified as a "roughage eater," able to use plants with a greater concentration of fiber (i.e., grasses) (Demmet and Van Soest 1983, Hofmann $1973 ;$ 1989). Our findings supported these classifications. Cattle ate plants found to be low in crude protein and digestibility, whereas deer used plants which were found to be high in crude protein and digestibility (Soltero-Gardea 1991; Ortega et al. 1997b).

Diet overlap ranged from 2 to $64 \%$. Winter and spring were the times of greatest overlap, particularly during year 2 under heavy stocking rates. The greatest overlap ( $>60 \%$ ) was observed in winter under the short-duration heavy stocking treatment, during both years.

The overlap between deer and cattle occurred when these ungulates were consuming western ragweed, Carolina geranium, evening primrose, wood-sorrel, and prairie coneflower. These are critical periods in which both domestic and wild ungulates tend to seek out new, rapidly growing plant species (Mackie 1978). During the second year, significant overlap (range $=48-64 \%$ ) occurred only on pastures heavily stocked by cattle.

In forested pine-hardwood, in central Louisiana, diet overlap between deer and cattle went from $12 \%$ in summer up to $46 \%$ in winter (Thill 1984). Deer in Louisiana are browsers (65\% browse in diet) and cattle are grazers (up to $74 \%$ grass in the diet); however, cattle can shift to browse (up to $48 \%$ ) which is the reason for the increased dietary overlap (Thill and Martin 1986, 1989). However, a high degree of trophic overlap is not sufficient evidence for competition. To demonstrate competition, data must be obtained showing diminished health or reproduction on one of the species involved in the interaction (Thill and Martin 1986). This aspect was outside the scope of our study.

\section{Use of Forage Classes}

Grass use by cattle in this study was lower than in previous studies carried out at the Welder Wildlife Refuge (Drawe 1967, Drawe and Box 1968, Drawe et al. 1988). Everitt et al. (1981) found that the year-round diet of cattle in the South Texas Plains (Hidalgo County) was comprised of $75 \%$ grasses and only $21 \%$ forbs. In the Edwards Plateau Region of Texas (Taylor et al. 1980), north-central Texas (Sanders 1975) and in northern Mexico (Chávez 1986) grasses were the dominant forage (above $90 \%$ ) for cattle, whereas forbs and browse were minor components.

Higher forb use (39\%) by cattle in this study should be of some concern since it is the main forage class for white-tailed deer in the area. In other studies, cattle used high amounts of forbs depending on the season (Launchbaugh et al. 1990) or the grazing system used (Pitts and Bryant 1987). In our study, the trend was for cattle to use more forbs and less grass under continuous than short-duration grazing 3 sampling periods. After that, there was no difference between continuous grazing and short-duration grazing in the use of forage classes by cattle. Similar findings were reported by Sanders (1975) when comparing continuous grazing and HILF grazing systems, or Taylor et al. (1980) when comparing short-duration grazing and Merrill grazing systems. Toward the last year of study, cattle tended to use more forbs and less grass under heavy than moderate stocking rates.

We found a high use of forbs by deer (range $=30$ to $80 \%$, average $=72 \%$ ) depending on the season, but Kie et al. (1980), also working at Welder, found that deer used a greater percentage (up to $95 \%$, average $81 \%$ ) of forbs than in this study, although they found similar consumption of grasses. Drawe (1967) found that deer at Welder Wildlife Refuge used more forbs on sandy (92\%) than on clay (69\%) soils. Our study was conducted on clay soil, which may explain the lower relative forb consumption.

Other deer diet studies have shown that deer are more browsers than grazers as in this study, but forb availability could have affected their results. Only $40 \mathrm{~km}$ northeast of Welder, at the Aransas National Wildlife Refuge, White (1973) determined that deer ate up to $67 \%$ browse and less than $30 \%$ forbs (most important use during mid-summer). By comparison, deer in the Rio Grande plains (Everitt and Drawe 1974, Everitt and Gonzalez 1979) used more browse (mostly cacti, up to $61 \%$ ) than our deer in the Texas Coastal Bend. Edwards Plateau deer also used more browse (50 to $70 \%$ ) than in the Rio Grande Plains or the Texas Coastal Bend (McMahan 1964, Bryant et al. 1979,1981; Waid 1983, Warren and Krysl 1983). Jackley (1991) found that whitetailed deer in the Edwards Plateau Region used high amounts of forbs (up to $52 \%$ ) when they were abundant. South-central Oklahoma deer shifted from a high use of forbs in spring and summer, to browse in the fall, to browse and grasses in winter (Van Vreede 1987).

Deer were affected by the grazing systems during the first winter and the second summer, obtaining more forbs in the continuous than in the short-duration grazing pastures. During fall and winter of 1987 it is clear that the greater consumption of forbs by deer in the continuously grazed treatments resulted in them being able to maintain a dietary crude protein above the maintenance level (Soltero-Gardea 1991; Ortega et al. 1997b). We expected that deer in the short-duration grazing heavy would do better since many grass species are "renewed" more often than in the continuous grazing. Evidently, repeated heavy grazing followed by 3-4 weeks of rest did not "renew" plants to render them more nutritious.

\section{Use of Plant Species}

Deer in this study used a variety of plant species, depending upon the season and the treatment. Few species were consistently 
used throughout the study period. Wood-sorrel was consistently used as it was available. However, the similar high use of woodsorrel in every treatment may be a reflection of selection of familiar food, perhaps a physiological adaptation (i.e., gut flora, digestive efficiency) (Partridge 1981). McCullough (1985) found that the George Reserve (MI) deer ate a wide array of species in all forage classes, showing high variation by season and between years. This reinforces the axiom that habitat management for deer should be directed to managing for diversity of plant species. Deer have evolved the ability to select a mix of forages that balance nutritional demands (Vangilder et al. 1982).

Across all treatments and periods, most important species used by cattle were buffalograss, pink tridens, and Texas wintergrass. Most important species for deer were wood-sorrel, widow's tears, and false dandelion.

Other species were important depending upon the season and the treatment. Western ragweed, prairie coneflower, bladderpod, and Carolina geranium were important to cattle in different seasons under different treatments. Some of the species important to deer, depending on the season and treatment, were browse such as mesquite beans and brasil, grasses such as longtom and little bluestem and forbs such as clay violet, loosestrife, bladderpod, prairie coneflower, Carolina geranium and bundleflower.

\section{Seasonal Sensitivity}

Neither grazing systems nor stocking rates directly affected deer in this study. Fall deer diets were the same in most of the treatments. During the winter deer became more selective, especially in the second winter, as their diets were differentially affected by the treatments. In the spring, deer selected the same diet regardless of the treatment where they were feeding. Summer was critical for deer. Deer were extremely selective; their diets were different depending upon the treatment where they fed. In summary, deer tended to be more selective during the summer and during drought, except for the spring months. Cattle were not as selective as deer during the drought. With the exception of the first summer, cattle ate similar diets across all treatments within seasons.

\section{Management Implications}

The Texas Coastal Bend is an area with the potential to produce quality deer because of high habitat diversity. Periodic droughts complicate selection of a grazing scheme that will avoid deterioration of the habitat for livestock and wildlife. Stocking rates should be carefully monitored during dry years because dietary overlap between cattle and deer was exacerbated under heavy stocking rates, particularly during winter, regardless of grazing system.

White-tailed deer were more sensitive to grazing systems than to stocking rates, but the overall impact of grazing systems was negligible. Deer are adapted to survive and thrive under adverse situations in which many other species might be at risk. A perfect example of this is the Edwards Plateau Region which contains 1 of the highest densities of white-tailed deer in the country (Jackley 1991) in spite of the diversity and pressure of livestock and exotic ungulates. Because greatest dietary overlap between cattle and deer occurred during winter under heavily stocked, short-duration pastures, ranchers should use moderate stocking and less intensive grazing systems during the winter.

Planning a grazing system in the Texas Coastal Bend should take into consideration many factors, such as range operation, economic constraints, management goals, class and kind of live- stock, wildlife and habitat management (Drawe 1985), and the high probability of having a drought. On the areas where the seral stage is high, such as the Welder Wildlife Refuge, a continuous grazing system may be the best solution, because of lower input costs and fewer management decisions and because deer consume slightly more forbs than in short-duration grazing. Alternatively, less intensive systems (e.g. Merrill) should be acceptable to achieve range improvement goals. Only moderate stocking rates should be used where deer are the primary concern. This avoids overgrazing during the periods of minimal forage growth (Matches and Burns 1985).

Most ungulate populations will survive even if their numbers are lowered because of a drought. Generally, they are able to adapt during critical periods by shifting their diets (Hansen and Reid 1975). White-tailed deer habitat should be managed to provide the greatest variety of plant species (Vangilder et al. 1982), thus minimizing the impact of "critical periods."

\section{Literature Cited}

Adams, N.E. 1978. The effects of cattle on white-tailed deer distribution. M.S. Thesis. Texas A\&I Univ., Kingsville, Tex.

Bryant, F.C. 1981. Foraging strategy of grazing animals. pp:193-198. In: L.D. White and A.L. Hoerman (eds.), Symp. Proc. 1981 Internat. Rancher's Roundup. Texas Agr. Ext. Ser, College Station, Tex.

Bryant, F.C., M.M. Kothmann, and L.B. Merrill. 1979. Diets of sheep, Angora goats, Spanish goats, and white-tailed deer under excellent range conditions. J. Range Manage. 32:412-417.

Bryant, F.C., C.A. Taylor, and L.B. Merrill. 1981. White-tailed deer diets from pastures in excellent and poor range condition. J. Range Manage. 34:193-200.

Chávez, A.H. 1986. Comparación del sistema de pastoreo continuo y corta duración, bajo dos intensidades de carga durante la época de sequía. M.S. Thesis. Univ. Autónoma de Chihuahua, Chihuahua, Mexico.

Cohen, W.E., D.L. Drawe, F.C. Bryant, and L.C. Bradley. 1989a. Observations on white-tailed deer and habitat response to livestock grazing in South Texas. J. Range Manage. 42:361-365.

Cohen, W.E., R.J. Reiner, F.C. Bryant, D.L. Drawe, and L.C. Bradley. 1989b. Daytime activity of white-tailed deer in response to short-duration and continuous grazing. Southwestern Nat. 34:482-431.

Demmet, M.W. and P.J. Van Soest. 1983. Body size, digestive capacity, and feeding strategies of herbivores. Wind. Inst. Intl. for Agr., Morrilton, Ark.

Drawe, D.L. 1967. Forage preferences of deer and cattle on the Welder Wildlife Refuge. M.S. Thesis Texas Tech. College, Lubbock, Tex.

Drawe, D.L. 1985. Grazing systems responses to drought: the Welder Wildlife Refuge case study. pp:37-46. In: R.D. Brown. Livestock and wildlife management during drought. Proc. Caesar Kleberg. Kingsville, Tex.

Drawe, D.L. and T.W. Box. 1968. Forage ratings for deer and cattle on the Welder Refuge. J. Range Manage. 21:225-228.

Drawe, D.L. and J.E. Cox. 1979. A coordinated range research program for the Welder Wildlife Foundation Refuge. Proc. First Welder Wildl. Found. Sym. 1:34 43 .

Drawe, D.L., J.R. Frasure, and B.E. Dahl. 1988. Effects of grazing management on cattle diets and nutrition in the Coastal Prairie. Tex. J. Agr. \& Nat. Res. 2:17-25.

Everitt, J.H. and D.L. Drawe. 1974. Spring food habits of white-tailed deer in the South Texas Plains. J. Range Manage. 27:15-20.

Everitt, J.H. and C.L. Gonzalez. 1979. Botanical composition and nutrient content of fall and early winter diets of white-tailed deer in south Texas. Southw. Nat. 24:297-310.

Everitt, J.H., C.L. Gonzales, G. Scott, and B.E. Dahl. 1981. Seasonal food preference of cattle on native range in the South Texas Plains. J. Range Manage. 34:384-388. 
Franklin, W.L. 1982. Contrasting socioecologies of South American wild camelids: the vicuña and the guanaco. p:573-629. In: J.F. Eisenberg and D.G. Kleiman (eds.). Advances in the study of mammalian behavior. Amer. Soc. Mammal. Special Publ. No. 7.

Gould, F.W. and T.W. Box. 1965. Grasses of the Texas Coastal Bend. Texas A\&M Univ., College Station, Tex.

Green, R.H. 1971. A multivariate statistical approach to the Hutchisonian niche: bivalve mollusks of central Canada. Ecol. 52:543-556.

Hanley, T.A. and K.A. Hanley. 1982. Food resource partitioning by sympatric ungulates on Great Basin rangeland. J. Range Manage. 35:152-158.

Hansen, R.M. and L.D. Reid. 1975. Diet overlap of deer, elk, and cattle in southern Colorado. J. Range Manage. 28:43-47.

Heitschmidt, R.K., R.A. Gordon, and J.S. Bluntzer. 1982. Short duration grazing at Texas experimental ranch: effects on forage quality. $J$. Range Manage. 35:372-374.

Hoffmann, R.R. 1973. The ruminant stomach: stomach structure and feeding habits of East African game ruminants. East Afr. Monogr. Biol., Vol. 2. Kenya Lit. Bur., Nairobi.

Hofmann, R.R. 1989. Evolutionary steps of ecophysiological adaptation and diversification of ruminants: a comparative view of their digestive system. Oecologia. 78:443-457.

Hyde, K.J. 1987. Effects of short duration grazing on white-tailed deer. M.S. Thesis. Texas A\&I Univ., Kingsville, Tex.

Jackley, J.J. 1991. Dietary overlap among axis, fallow, sika, and whitetailed deer in the Edwards Plateau region of Texas. M.S. Thesis. Tech Univ. Lubbock, Tex.

Jones, F.B. 1982. Flora of the Texas Coastal Bend. Contribution B-6. Third Edition. Welder Wildl. Found. Sinton, Tex.

Keddy, P.A. 1989. Competition. Chapman and Hall. London, England.

Kie, J.G, D.L. Drawe, and G. Scott. 1980. Changes in diet and nutrition with increased herd size in Texas white-tailed deer. J. Range Manage. 33:28-34.

Klecka, W.R. 1980. Discriminant analysis. Sage University Paper series Quantitative Applications in the Social Sciences, series no. 19. Beverly Hills and London: Sage Pub.

La Gory, K.E., C. Bagshaw, III, and L. Brisbin, Jr. 1991. Niche differences between male and female white-tailed deer on Ossabaw Island, Georgia. App. Anim. Behav. Sci. 29:205-214.

Launchbaugh, K.L., J.W. Stuth, and J.W. Holloway. 1990. Influence of range site on diet selection and nutrient intake of cattle. J. Range Manage. 43:109-116.

Lindeman, R.H., P.F. Merenda, and R.Z. Gold. 1980. Introduction to bivariate and multivariate analysis. Scott, Foresman and Co. Glenview, III.

Mackie, R.J. 1978. Impacts of livestock grazing on wild ungulates. North-Amer. Wildl. Conf. 43:462-476.

Magurran, A.E. 1988. Ecological diversity and its measurement. Princeton Univ. Press. Princeton, N.J.

Matches, A.G. and J.C. Burns. 1985. Systems of grazing management. pp:537-547. In: M.E. Heath, R.F. Barnes, and D.S. Metcalfe (eds.) Forages, the science of grassland agriculture. Iowa State Univ. Press, Ames, Iowa.

McCullough, D.R. 1985. Variables influencing food habits of whitetailed deer on the George Reserve. J. Mammal. 66:682-692

McMahan, C.A. 1964. Comparative food habits of deer and three classes of livestock. J. Wildl. Manage. 28:798-808.

Nagy, J.G., T. Hakonson, and K.L. Knox. 1969. Effects of quality on food intake in deer. Trans. North. Amer. Wildl. Nat. Res. Conf. 34:146-154.

Ortega, I.M. 1991. Taming captive-born and wild-born white-tailed deer fawns. Tex J.Sci. 43:215-217.

Ortega, I.M., F.C. Bryant, and D.L. Drawe. 1995. Contrast of esophageal-fistula versus bite-count techniques to determine cattle diets. J. Range Manage. 48:498-502.

Ortega, I.M., L.D. Perry, D.L. Drawe, and F.C. Bryant. 1990. Observations on obtaining white-tailed deer fawns for experimental purposes. Tex. J. Sci. 42: 69-72.

Ortega, I.M., S. Soltero-Gardea, F.C. Bryant, and D.L. Drawe. 1997a. Evaluating grazing strategies for cattle: Deer forage dynamics. J. Range Manage. 50: 615-621.
Ortega, I.M., S. Soltero-Gardea, D.L. Drawe, and F.C. Bryant. 1997b. Evaluating grazing strategies for cattle: Nutrition of cattle and deer. J. Range. Manage. 50:631-637.

Ott, L. 1988. An introduction to statistical methods and data analysis. Third Edition. PWS-KENT Publ. Co. Boston. Mass.

Partridge, L. 1981. Increased preference for familiar food in small mammals. Anim. Behav. 29:211-216.

Pianka, E.R. 1973. The structure of lizard communities. Ann. Rev. Ecol. and Syst. 4:53-74.

Pianka, E.R. 1983. Evolutionary ecology. Harper and Row Publishers. N.Y.

Pitts, J.S. and F.C. Bryant. 1987. Steer and vegetation response to short-duration and continuous grazing. J. Range Manage. 40:386-389.

San Martin, F. and F.C. Bryant. 1987. Nutrición de los camélidos sudamericanos: estado general de nuestro conocimiento. Artículo Técnico T-9-505. College of Agr. Scie. Texas Tech Univ., Lubbock, Tex.

Sanders, K.D. 1975. Continuous vs. short duration grazing on NorthCentral Texas rangelands. Ph.D. Diss. Texas Tech Univ., Lubbock, Tex.

Sanders, K.D., B.E. Dahl, and G. Scott. 1980. Bite-count vs. fecal analysis for range diets. J. Range Manage. 33:146-149.

SAS. 1985. SAS User's Guide: Statistics, Version 5 Edition. SAS Institute Inc. Cary, N.C.

Savory, A. and S. Parson. 1980. The Savory grazing method. Rangeland. 2:234-237.

Schwartz, C.C. and J.E. Ellis. 1981. Feeding ecology and niche separation in some native and domestic ungulates on the short grass prairie. J. App. Ecol. 18:343-353.

Scott, G. and B.E. Dahl. 1980. Key to selected plant species of Texas using plant fragments. Occasional papers, The Museum, Texas Tech Univ., Lubbock, Tex.

Soltero-Gardea, S. 1991. Phytomass dynamics and deer and cattle nutrition under different grazing practices in the Texas Coastal Bend. Ph.D. Diss. Texas Tech Univ., Lubbock, Tex.

Steel, R.G.D. and J.H. Torrie. 1980. Principles and procedures of statistics: A biometrical approach. 2nd. Ed. McGraw-Hill Book Co., N.Y.

Taylor, C.A., M.M. Kothmann, L.B. Merrill, and D. Elledge. 1980. Diet selection by cattle under high-intensity low-frequency, short duration, and Merrill grazing systems. J. Range Manage. 33:428-434.

Thill, R.E. 1984. Deer and cattle on Louisiana pine-hardwood sites. J. Wildl. Manage. 48:788-798.

Thill, R.E. and A. Martin, Jr. 1986. Deer and cattle diet overlap on Louisiana pine-bluestem range. J. Wildl. Manage. 50:707-713.

Thill, R.E. and A. Martin, Jr. 1989. Deer and cattle diets on heavily grazed pine-bluestem range. J.Wildl.Manage. 53:540-548.

Van Vreede, G. 1987. Seasonal diets of white-tailed deer in south-central Oklahoma. M.S. Thesis. Texas Tech Univ., Lubbock, Tex.

Vangilder, L.D., O. Torgerson, and W.R. Porath. 1982. Factors influencing diet selection by white-tailed deer. J. Wildl. Manage. 46:711-718.

Waid, D.D. 1983. Physiological indices and food habits of deer in central Texas. M.S. Thesis. Tech Univ., Lubbock, Tex.

Warren, RJ. and L.J. Krysl. 1983. White-tailed deer food habits and nutritional status as affected by grazing and deer-harvest management. J. Range Manage. 36:104-109.

White, M. 1973. The whitetail deer of the Aransas National Wildlife Refuge. Texas J. Sci. 24:457-489.

Wolda, H. 1981. Similarity indices, sample size, and diversity. Oecol. 50:296-302. 